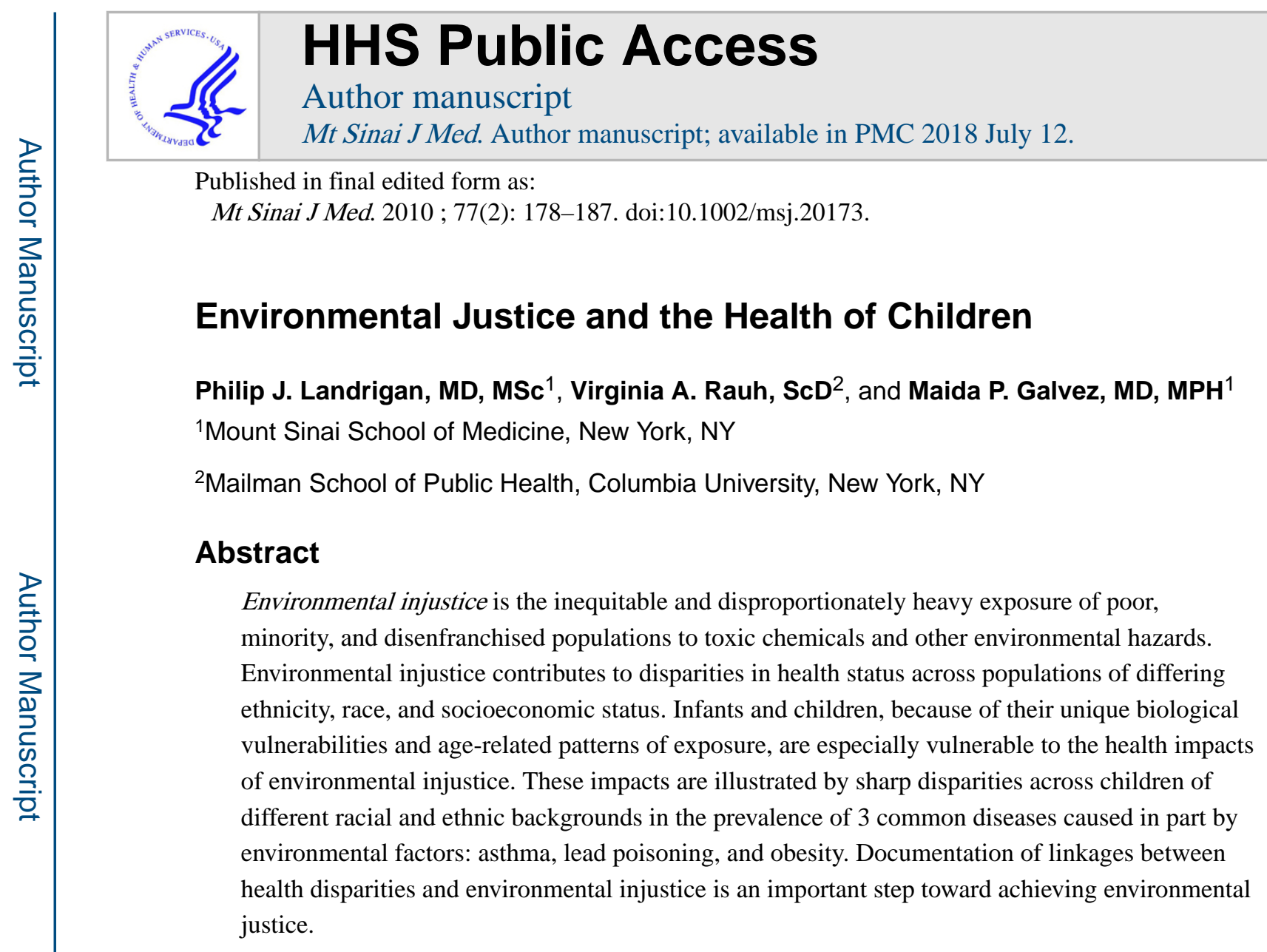

\title{
Keywords
}

children's environmental health; environmental justice; lead poisoning; air pollution; asthma; obesity; built environment

Environmental injustice is the inequitable and disproportionately heavy exposure of poor, minority, and disenfranchised populations to toxic chemicals, contaminated air and water, unsafe workplaces, and other environmental hazards. ${ }^{1-3}$ The concept of environmental injustice was first developed in the 1980s in studies of hazardous waste sites in the Southeastern United States. ${ }^{1}$ These studies found that waste sites in the Southeast are located disproportionately in poor counties inhabited largely by African Americans, Native Americans, and other marginalized populations. A similar distribution of hazardous waste sites was subsequently documented in New England. ${ }^{4}$ The concept of environmental injustice has been further elaborated in studies examining ethnic disparities in exposures to automotive exhaust and ambient air pollution ${ }^{5-7}$; in studies in New York City documenting that virtually all diesel bus depots, places at which buses may idle for hours while emitting pollutants, are located in minority, mostly disadvantaged neighborhoods ${ }^{8}$; in studies examining disparities in housing quality ${ }^{9}$; and in studies of residential proximity to polluting industrial facilities. ${ }^{10}$ Environmental injustice has been well documented in occupational

Address Correspondence to: Philip J. Landrigan, Mount Sinai School of Medicine, New York, NY, phil.landrigan@mssm.edu. DISCLOSURES

Potential conflict of interest: Nothing to report. 
settings. ${ }^{11}$ It has served as an operational concept to guide pollution prevention programs. 12,13

Environmental injustice is highly correlated with other factors that link poverty to poor health, including inadequate access to medical and preventive care, lack of safe play spaces for children, lack of access to healthful foods, absence of good jobs, crime, and violence. ${ }^{2}$ Environmental injustice contributes to disparities in health status across populations of different ethnic, racial, and socioeconomic backgrounds, such as differences in the incidence and prevalence of asthma, ${ }^{5-7}$ obesity, ${ }^{14,15}$ diabetes, ${ }^{16}$ lung cancer, ${ }^{5}$ and a range of mental health and developmental problems. ${ }^{17-19}$

Children are especially vulnerable to the health impacts of environmental injustice. Children's unique, age-related patterns of exposure and their developmentally defined windows of susceptibility ${ }^{20}$ magnify the impacts of environmental injustice. Through case studies of 3 diseases caused entirely or in part by environmental exposures-asthma, lead poisoning, and obesity-this report examines the consequences of toxic environmental exposures and environmental injustice for the health of children.

\section{ENVIRONMENT AND HUMAN HEALTH}

Hazardous exposures in the environment are potent causes of disease, disability, and death in persons of all ages and especially in infants and children.

The power of the environment to influence patterns of disease and death is illustrated by the extraordinary changes in morbidity and mortality that have occurred over the past century in industrially developed countries, changes unprecedented in human history. Life expectancy at birth has increased more than $50 \% .^{21}$ Infant mortality has declined more than $90 \%$. The ancient infectious diseases-smallpox, cholera, yellow fever, polio, measles, and bubonic plague-are no longer the dominant causes of disease and death. ${ }^{22}$

These changes occurred in parallel with large-scale environmental changes-the delivery of safe drinking water; the provision of sufficient, wholesome food; the removal of sewage; the control of insect vectors; and the construction of decent housing-and were largely driven by these changes. It is noteworthy that the decline in mortality that marked the start of the epidemiological transition began in the United States in the 1860s, soon after the construction of major urban water systems and nearly 80 years before the discovery of penicillin and more than a century before the first organ transplant (see Figure 1).

Today, in the aftermath of the epidemiological revolution, the principal diseases of American children are a group of chronic diseases termed the new pediatric morbidity. ${ }^{23}$ These diseases are the major causes of illness and death in American children today:

- Asthma, which has more than doubled in frequency since 1980 and become the leading cause of pediatric hospitalization and school absenteeism of American children. Rates of asthma have risen especially rapidly among poor children of color residing in inner-city communities. ${ }^{24}$ 
- $\quad$ Birth defects, which are now the leading cause of infant death. Certain birth defects of the male reproductive organs, such as hypospadias, have doubled in frequency. ${ }^{25,26}$

- Neurodevelopmental disorders, such as dyslexia, mental retardation, attention deficit/hyperactivity disorder, and autism. These conditions affect $5 \%$ to $10 \%$ of the 4 million babies born each year in the United States. The reported frequency is sharply increasing. ${ }^{27}$

- Leukemia and brain cancer in children, which have increased in reported incidence since the 1970s, despite declining mortality. ${ }^{28,29}$ Cancer is now the second leading cause of death in American children and is surpassed only by traumatic injuries.

- $\quad$ Preterm birth, which has increased in incidence by $27 \%$ since 1981.

- Obesity, which has trebled in prevalence, and its result, type 2 diabetes. In 2005, $41 \%$ of 5 -year-old children entering kindergarten in the 5 boroughs of New York City were found to be overweight or obese. Obesity is especially prevalent in African American and Latino children. ${ }^{30}$

\section{CHILDREN'S EXPOSURES TO TOXIC CHEMICALS IN THE ENVIRONMENT}

Children's environments have changed profoundly in the past century. Children today are at risk of exposure to more than 80,000 synthetic chemicals. Most of these chemicals are newly invented, and nearly all of them did not exist 50 years ago. They include plastics, pesticides, motor fuels, building materials, antibiotics, chemotherapeutic agents, flame retardants, and synthetic hormones. ${ }^{31}$ Children are especially at risk of exposure to the 3000 synthetic chemicals that are produced in quantities of 1 million pounds or more per year. These high production volume (HPV) chemicals are the synthetic materials used most extensively in industry and consumer products and most widely dispersed in the environment: in air, food, water, homes, schools, and communities. Measurable levels of several hundred HPV chemicals have been documented in Centers for Disease Control and Prevention surveys in the bodies of most Americans. ${ }^{32}$ Measurable levels of HPV chemicals have been documented also in the breast milk of nursing mothers and in the cord blood of newborn infants. ${ }^{33}$

\section{WIDESPREAD FAILURE TO TEST CHEMICALS FOR TOXICITY}

A high proportion of the most widely used synthetic chemicals have never been tested for their possible toxicity. ${ }^{34}$ Information on potential toxicity is publicly available for only about two-thirds of the $3000 \mathrm{HPV}$ chemicals. Information on possible developmental toxicity or the potential capacity to cause injury to infants and children is especially lacking. This information is available for less than one-third of HPV chemicals. ${ }^{34}$

Failure to test chemicals for toxicity represents a serious lapse of responsible stewardship. It puts children at risk on a daily basis to exposure to chemicals whose hazardous potential is virtually unknown. It reflects a combination of industry's unwillingness to take 
responsibility for the products that it produces coupled with a failure of the government to regulate the use of these products.

Governmental failure in this area flows from the failure of the Toxic Substances Control Act (TSCA). ${ }^{35}$ TSCA was intended at the time of its passage in 1976 to be pioneering legislation that would require premarket evaluation of all new chemicals for potential toxicity and also require retroactive testing of tens of thousands of industrial chemicals that were already in commerce. In fact, however, TSCA has been a dismal failure. A particularly egregious example of this failure was a decision made soon after the passage of TSCA to grandfather in, with no toxicity testing, 62,000 chemicals that were already on the market. These chemicals were simply presumed to be safe and allowed to remain in commerce. The office within the US Environmental Protection Agency responsible for enforcing TSCA has been chronically underfunded, understaffed, and overwhelmed by the sheer number of new chemicals and technologies that come before it. By default, emerging chemicals and new products are presumed by Environmental Protection Agency regulators to be safe unless there is overwhelming evidence of their potential to cause harm.

\section{CHILDREN'S UNIQUE VULNERABILITY TO TOXIC CHEMICALS}

Children are now understood to be fundamentally more vulnerable than adults to toxic chemicals in the environment. ${ }^{20}$ Four differences between children and adults contribute to children's increased susceptibility:

- Children have disproportionately heavier exposures to chemicals in comparison with adults. This reflects children's greater consumption per pound of body weight of food, water, and air. Thus, a child in the first year of life drinks 7 times more water per pound per day than an adult. These dietary exposures are further magnified by children's unique behaviors: their play close to the floor and their oral-exploratory behavior both permit all too easy access to toxic materials in rugs, dust, and soil.

- $\quad$ Children's metabolic pathways, especially in the first months after birth, are immature. In many instances, children are less able than adults to break down and excrete toxic compounds. Thus, organophosphate pesticides linger in the bloodstream of a child for 36 hours, whereas most adults are able to clear and excrete these dangerous materials in 6 hours and thus minimize damage.

- $\quad$ Children are undergoing rapid growth and development. Early development creates windows of great vulnerability. Witness, for example, the uniquely tragic consequences of exposures in early life to substances such as thalidomide, diethylstilbestrol, and methyl mercury.

- $\quad$ Because children have more years of future life than most adults, they have more time to develop chronic diseases that may be initiated by early exposures. 


\section{EVIDENCE THAT TOXIC ENVIRONMENTAL EXPOSURES CONTRIBUTE TO MAJOR CHILDHOOD DISEASES}

Evidence has been building for 100 years that toxic exposures in the environment can cause and aggravate disease in children. ${ }^{36}$ This body of evidence has become especially compelling in the past 2 decades:

- $\quad$ Rates of asthma are increased in children exposed to second-hand cigarette smoke. ${ }^{37}$

- Rates of asthma are increased in children exposed to particulate air pollution. $38-40$

- $\quad$ Risk of sudden infant death syndrome is increased in babies exposed to particulate air pollution. ${ }^{41}$

- $\quad$ Neurodevelopmental impairment with a reduced intelligence quotient (IQ), shortening of attention span, and disruption of behavior is increased in children exposed to lead. ${ }^{42-46}$

- Neurodevelopmental impairment with a reduction of IQ is increased in children exposed to polychlorinated biphenyls. ${ }^{47}$

- $\quad$ Neurodevelopmental impairment with a reduction of IQ and shortening of attention span is increased in children exposed prenatally to methyl mercury. ${ }^{48}$

- Lower birth weight, smaller head circumference at birth, and subsequent developmental delays are increased in children exposed prenatally to the organophosphate pesticide chlorpyrifos. ${ }^{49,50}$

- $\quad$ Neurodevelopmental impairment with a reduction of IQ and disruption of behavior is increased in children exposed prenatally to ethyl alcohol; this is called fetal alcohol syndrome. ${ }^{51}$

- There is an increased risk of preterm birth associated with prenatal exposure to tobacco smoke and dichlorodiphenyltrichloroethane. ${ }^{52}$

Many of these epidemiological findings have been translated into evidence-based programs of prevention. These prevention programs have yielded enormous gains for children's health. Examples include the following:

- The finding that alcohol and tobacco exposure during pregnancy can cause brain damage and growth restriction in infants has been successfully translated into public health intervention programs that have reduced alcohol consumption and tobacco use during pregnancy. These programs have led to the prevention of fetal alcohol syndrome and intrauterine growth retardation. ${ }^{53,54}$

- $\quad$ The finding that $\mathrm{X}$-ray exposure during pregnancy increases the risk of childhood cancer has triggered minimization during pregnancy of diagnostic X-rays. This change in medical practice has prevented thousands of cases of childhood leukemia. ${ }^{55}$ 
- $\quad$ Removal of lead from gasoline, following the discovery that low-dose exposures to lead could cause infant brain damage with a loss of intelligence and disruption of behavior, has resulted in a $90 \%$ reduction in childhood blood lead levels and lead poisoning. ${ }^{43}$

- A reduction in children's exposure to arsenic in well water has brought about a reduction in the risk of skin and liver cancer in exposed children. ${ }^{56}$

\section{ENVIRONMENTAL INJUSTICE}

Well-studied examples of environmental injustice in the United States include the disproportionate exposure of poor and minority communities to hazardous waste sites, lead paint, air pollution, substandard housing, dangerous jobs, and polluting industries. Such environmental risk factors are disproportionately concentrated in poor communities and in communities inhabited by people of color. ${ }^{1-13}$

Disproportionate exposures of persons in poor communities and in communities inhabited by people of color to toxic environmental hazards appear to contribute significantly to welldocumented disparities in health. Environmental injustice is linked to increased risks of many diseases. These linkages are especially evident in children because of children's unique vulnerabilities to environmental hazards. ${ }^{20}$ Three examples are now discussed.

\section{Asthma}

Asthma is the most common chronic disease of American children and is the leading cause of pediatric emergency department visits, pediatric hospitalizations, and school absenteeism. Well-described environmental risk factors for asthma include ambient air pollution from industrial and vehicular sources, indoor air pollution, secondhand cigarette smoke, mold, mildew, and cockroach droppings. ${ }^{57}$

The incidence, prevalence, and hospitalization rates for asthma in the United States are all disproportionately high in poor communities. ${ }^{58}$ The highest rates are seen among poor minority children living in inner-city communities, For example, the prevalence of childhood asthma in certain low-income, minority neighborhoods in New York is as high as $23 \%$, which is approximately 4 times the national average. Current US asthma prevalence is

- $\quad$ Higher in blacks $(9.2 \%)$ than in whites $(6.9 \%)$.

- Higher in persons of Puerto Rican descent (14.5\%) than in those of Mexican descent (3.9\%).

- Higher in those below the federal poverty level (10.3\%) than in those at or above the federal poverty level $(6.4 \%-7.9 \%) .57,59,60$

Disproportionate exposures to ambient air pollutants in poor communities are a clear example of environmental injustice associated with elevated rates of asthma. Among the ambient air pollutants found in especially high concentrations in poor, minority neighborhoods are fine particulates, ozone, and oxides of nitrogen. Bus depots, in which diesel buses were historically permitted to idle for hours on end, are an important source of 
ambient air pollutants in poor neighborhoods. Six of the 7 bus depots in all of Manhattan are located in either Harlem or East Harlem.

Disproportionate exposure to indoor air pollution in poor neighborhoods further increases the risk of asthma. ${ }^{61,62}$ Among the indoor air pollutants documented to be disproportionately present in poor communities are environmental (second-hand) tobacco smoke, mold and mildew, animal dander, and cockroach droppings.

Public housing may be a particular risk factor for asthma and a further example of environmental injustice. In New York City, for example, within communities with high asthma rates, asthmatics were 5 times more likely than nonasthmatics to live in public housing. Also, short-term housing used by transient individuals is likely to be characterized by poorer quality management and upkeep, with conditions that can trigger asthma symptoms in those without permanent homes. ${ }^{63,64}$

\section{Lead Poisoning}

Lead is one of the best known and most extensively studied of the toxic chemicals in the environment. ${ }^{42}$

The most important environmental source of lead exposure for children in the United States is lead-based paint in housing built before 1978 and the lead-contaminated dust that arises from the abrasion, flaking, and chipping of lead-based paint. The major route of children's exposure to lead from paint is the ingestion of lead-contaminated dust. Children between the ages of 1 and 6 years are at the highest risk of lead exposure because the oral-exploratory, hand-to-mouth behavior that is so normal in this age group facilitates the transfer of lead dust from the environment into children's bodies.

Lead is now understood to be toxic to children at every level of exposure. High-level exposure causes acute poisoning with coma and convulsions. Lower level exposure, too low to produce symptoms, still causes injury to the brain and other organ systems. ${ }^{42}$ Diminished intelligence, shortening of attention span, reading problems, attention deficit/hyperactivity disorder, school failure, delinquency, and criminal behavior are the consequences of exposure to lead. ${ }^{44,45}$ These effects are lifelong, and they cannot be cured by any current medical treatment. There is no evidence of a threshold level below which lead does not cause these harmful effects on children's health. ${ }^{46}$

Lead poisoning is disproportionately concentrated in poor minority communities in the United States (see Figure 2). This reflects the fact that older (pre-1978) housing units that are in poor repair are disproportionately concentrated in these neighborhoods. The resulting environmental injustice is documented in the sharp disparities observed in the distribution of elevated blood lead levels in American children by race and income. Thus, $4.6 \%$ of African American children are estimated to have blood lead concentrations above $25 \mu \mathrm{g} / \mathrm{dL}$ versus $1.2 \%$ of white children. ${ }^{43}$ In New York City, lead poisoning is found almost exclusively among African American and Hispanic children. 


\section{Obesity}

Obesity is the single childhood condition in the United States that is rapidly worsening. ${ }^{65-67}$ It is estimated that $17 \%$ of children 6 to 11 years old are obese versus $4 \%$ during $1971-$ 1974.

Sharp disparities exist by race, income, and ethnicity in the prevalence of childhood obesity. It is well documented that minority children, specifically Mexican Americans and nonHispanic blacks, have a higher prevalence of obesity than non-Hispanic white populations. ${ }^{68}$ Prevalence rates of childhood obesity in New York City public elementary school students further illustrate these national trends, with Latinos (31\%) and African Americans (23\%) at disproportionate risk in comparison with their white counterparts (16\%). ${ }^{69}$ These very same minority populations are at higher risk for obesity-related sequelae, including cardiovascular disease, stroke, type 2 diabetes, and metabolic syndrome. ${ }^{68,69-75}$

Ecological systems theory highlights the importance of considering the role of the ecological niche in order to understand health outcomes. ${ }^{76}$ When ecological systems theory is being applied to childhood obesity, Davison and Birch ${ }^{76}$ recommend the consideration of contextual factors within children's families and the school, community, and society at large that specifically influence children's dietary and physical activity behaviors and hence risk for obesity. These factors, often called in the literature the built environment, may include crowded streets, a lack of outdoor play spaces, easy access to fast foods and junk foods, limited access to fresh, healthy foods, and substandard housing. ${ }^{77}$ Extensive research has documented that each of these risk factors is disproportionately common in poor neighborhoods, ${ }^{78,79}$ the very same communities already at increased risk for obesity.

The built environment research has taken a multilevel approach to tackling the obesity epidemic by searching for evidence-based interventions and health policies that promote healthy communities. These novel approaches have focused on diverse environmental risk factors and include reducing access to unhealthy snacks by eliminating soda and snack machines from schools nationwide, ${ }^{80}$ banning transfats from restaurants and requiring fast food restaurants to post calorie counts, ${ }^{81}$ increasing access to green markets, ${ }^{82}$ providing walking and bicycling trails, ${ }^{83}$ adopting bike share programs in urban areas, ${ }^{84}$ altering parks and other recreational spaces to optimize activity levels, ${ }^{85}$ and developing walkable communities. ${ }^{86}$ Information gained from further interdisciplinary, longitudinal cohort studies of children can inform multifaceted obesity interventions such as food policy and urban planning initiatives that promote public health.

Recent research is also examining microenvironmental factors and specifically exposure to chemicals with the potential to mimic hormones, which are commonly called endocrine disruptors. ${ }^{87-89}$ Reports of endocrine disruptors such as phthalates and bisphenol A have been widespread in the media because of concerns that universal exposures in the US population, with the highest levels typically found in children, may be associated with health effects, including obesity and diabetes. ${ }^{90,91}$ Although further human studies are needed, this demonstrates another potentially important area of environmental intervention with respect to tackling the epidemic of childhood obesity. 


\section{CONCLUSION}

Disease of environmental origin is preventable. Disease caused by environmental degradation and environmental injustice is the result of human activity and is therefore preventable through modification or cessation of the activity that damages or pollutes the environment.

To begin to address environmental injustice and its consequences for human health, we need solid evidence-based research on the long-term human health effects of exposure to a range of physical, chemical, and social exposures beginning before conception and continuing throughout childhood into adulthood. ${ }^{92-94}$ Prospective epidemiological studies assessing exposure-health associations, including biomarkers of exposure and finely tuned neuropsychological and behavioral endpoints, are desperately needed. These studies must be conducted within and across populations to document inequalities in exposure as well as susceptibility to the effects of toxic exposures. They need to be designed and implemented with strong community participation at every stage.

In addition, we need to recognize that inequalities in exposures arise at both the community and individual levels, so efforts to redress these disparities cannot be limited to behavioral interventions. Broad societal efforts and a reordering of priorities are needed to redress social and structural conditions that result in unacceptably high levels of toxic exposure for whole populations. ${ }^{94}$ Protection of the vulnerable must become a moral and ethical beacon that guides decision making at all levels of government and business. An example of such enlightened decision making is to be found in the Food Quality Protection Act of 1996. ${ }^{95}$ This is the major federal pesticide law in the United States, and it is the only federal environmental statute that makes explicit provision for the protection of children's health in the setting of pesticide standards.

As a result of environmental injustice, too many American children live their lives burdened by biological and social conditions that severely limit their potential for success. The effects on children are the cruelest consequences of environmental injustice. Beyond childhood, the disproportionate exposure in early life of children in poor communities to environmental hazards sets the stage for a lifetime of suboptimal health and diminished achievement and thus helps to perpetuate the intergenerational cycle of disenfranchisement and poverty. ${ }^{96}$

\section{References}

1. Bullard RD, Wright BH. Environmental justice for all: community perspectives on health and research needs. Toxicol Ind Health. 1993; 9:821-841. [PubMed: 8184445]

2. Brulle RJ, Pellow DN. Environmental justice: human health and environmental inequalities. Annu Rev Public Health. 2006; 27:103-124. [PubMed: 16533111]

3. Birnbaum LS, Zenick H, Brance CM. Environmental justice: a continuing commitment to an evolving concept. Am J Public Health. 2009; 99(suppl 3):S487-S489. [PubMed: 19890144]

4. Faber DR, Krieg EJ. Unequal exposure to ecological hazards: environmental injustices in the Commonwealth of Massachusetts. Environ Health Perspect. 2002; 110(suppl 2):277-288.

5. McEntee JC, Ogneva-Himmelberger Y. Diesel particulate matter, lung cancer, and asthma incidences along major traffic corridors in MA, USA: a GIS analysis. Health Place. 2008; 14:817828. [PubMed: 18280198] 
6. Chakraborty J, Zandbergen PA. Children at risk: measuring racial/ethnic disparities in potential exposure to air pollution at school and home. J Epidemiol Community Health. 2007; 61:1074-1079. [PubMed: 18000130]

7. Maantay J. Asthma and air pollution in the Bronx: methodological and data considerations in using GIS for environmental justice and health research. Health Place. 2007; 13:32-56. [PubMed: 16311064]

8. Vásquez VB, Minkler M, Shepard P. Promoting environmental health policy through community based participatory research: a case study from Harlem, New York. J Urban Health. 2006; 83:101110. [PubMed: 16736358]

9. Rauh VA, Landrigan PJ, Claudio L. Housing and health: intersection of poverty and environmental exposures. Ann N Y Acad Sci. 2008; 1136:276-288. [PubMed: 18579887]

10. Mohai P, Lantz PM, Morenoff J, et al. Racial and socioeconomic disparities in residential proximity to polluting industrial facilities: evidence from the Americans' Changing Lives Study. Am J Public Health. 2009; 99(suppl 3):S649-S656. [PubMed: 19890171]

11. Farquhar SA, Goff NM, Shadbeh N, et al. Occupational health and safety status of indigenous and Latino farmworkers in Oregon. J Agric Saf Health. 2009; 15:89-102. [PubMed: 19266886]

12. Sexton K, Olden K, Johnson BL. "Environmental justice": the central role of research in establishing a credible scientific foundation for informed decision making. Toxicol Ind Health. 1993; 9:685-727. [PubMed: 8184441]

13. Shendell DG, Rawling MM, Foster C, et al. The outdoor air quality flag program in central California: a school-based educational intervention to potentially help reduce children's exposure to environmental asthma triggers. J Environ Health. 2007; 70:28-31. [PubMed: 17941400]

14. Sturm R, Datar A. Body mass index in elementary school children, metropolitan area food prices, and food outlet density. Public Health. 2005; 119:1059-1068. [PubMed: 16140349]

15. Sturm R. Disparities in the food environment surrounding US middle and high schools. Public Health. 2008; 122:681-690. [PubMed: 18207475]

16. Horowitz CR, Colson KA, Hebert PL, Lancaster K. Barriers to buying healthy foods for people with diabetes: evidence of environmental disparities. Am J Public Health. 2004; 94:1549-1554. [PubMed: 15333313]

17. Xue Y, Leventhal T, Brooks-Gunn J, Earls FJ. Neighborhood residence and mental health problems of 5- to 11-year-olds. Arch Gen Psychiatry. 2005; 62:554-563. [PubMed: 15867109]

18. Spencer N. Social, economic, and political determinants of child health. Pediatrics. 2003; 112(pt 2):704-706. [PubMed: 12949325]

19. Schneiders J, Drukker M, van der Ende J, et al. Neighbourhood socioeconomic disadvantage and behavioural problems from late childhood into early adolescence. J Epidemiol Community Health. 2003; 57:699-703. [PubMed: 12933776]

20. National Academy of SciencesPesticides in the Diets of Infants and Children Washington, DC: National Academy Press; 1993

21. Hoyert DL, Matthews TJ, Meacker F, et al. Annual summary of vital statistics: 2004. Pediatrics. 2006; 117:168-183. [PubMed: 16396875]

22. Omran AR. The epidemiologic transition: a theory of the epidemiology of population change. Milbank Mem Fund Q. 1971; 49:509-538. [PubMed: 5155251]

23. Haggerty R, , Rothman J. Child Health and the Community New York, NY: John Wiley \& Sons; 1975

24. Akinbami LJ, Schoendorf KC. Trends in childhood asthma: prevalence, health care utilization and mortality. Pediatrics. 2002; 110(pt 1):315-322. [PubMed: 12165584]

25. Centers for Disease Control and Prevention. Improved national prevalence estimates for 18 selected major birth defects-United States, 1999-2001. MMWR Morb Mortal Wkly Rep. 2006; 54:1301-1305. [PubMed: 16397457]

26. Paulozzi LJ, Erickson JD, Jackson RJ. Hypospadias trends in two US surveillance systems. Pediatrics. 1997; 100:831-834. [PubMed: 9346983]

27. Boyle CA, Cordero JF. Birth defects and disabilities: a public health issue for the 21 st century. Am J Public Health. 2005; 95:1884-1886. [PubMed: 16195507] 
28. National Cancer Institute. SEER database http://seer.cancer.gov. Accessed January 2010

29. Devesa SS, Blot WJ, Stone BJ, et al. Recent cancer trends in the United States. J Natl Cancer Inst. 1995; 87:175-182. [PubMed: 7707404]

30. Ogden CL, Carroll MD, Curtin LR, et al. Prevalence of overweight and obesity in the United States, 1999-2004. JAMA. 2006; 295:1549-1555. [PubMed: 16595758]

31. Chemicals in Commerce Information System (Chemical Update System Database) Washington, DC: US Environmental Protection Agency; 1998

32. Centers for Disease Control and PreventionThird National Report on Human Exposure to Environmental Chemicals Atlanta, GA: National Center for Environmental Health; 2005 http:// www.cdc.gov/exposurereport/. Accessed January 2010

33. Houlihan J, , Kropp T, , Wiles R. , et al. Body burden: the pollution in newborns http:// www.ewg.org/reports/bodyburden2/execsumm.php. Published July 14, 2005. Accessed January 2010

34. Goldman LR. Chemicals and children's environment: what we don't know about risks. Environ Health Perspect. 1998; 106(suppl 3):875-880. [PubMed: 9646051]

35. Congress US. Toxic Substances Control Act [as amended through PL Dec 31, 2002107377 http:// epw.senate.gov/tsca.pdf. Accessed January 2010

36. Miller RW. How environmental hazards in childhood have been discovered: carcinogens, teratogens, neurotoxicants, and others. Pediatrics. 2004; 113(suppl):945-951. [PubMed: 15060186]

37. Salam MT, Li YF, Langholz B, Gilliland FD. Early-life environmental risk factors for asthma: findings from the Children's Health Study. Lancet. 2004; 363:119-125. [PubMed: 14726165]

38. Gauderman WJ, Avol E, Gilliland F, et al. The effect of air pollution on lung development from 10 to 18 years of age. N Engl J Med. 2004; 351:1057-1067. [PubMed: 15356303]

39. Friedman MS, Powell KE, Hutwagner L, et al. Impact of changes in transportation and commuting behaviors during the 1996 Summer Olympic Games in Atlanta on air quality and childhood asthma. JAMA. 2001; 285:897-905. [PubMed: 11180733]

40. Suh HH, Bahadori T, Vallarino J, Spengler JD. Criteria air pollutants and toxic air pollutants. Environ Health Perspect. 2000; 108(suppl 4):625-633. [PubMed: 10940240]

41. Woodruff T, Grillo J, Schoendorf C. The relationship between selected causes of postneonatal infant mortality and particulate air pollution in the United States. Environ Health Perspect. 1997; 105:608-612. [PubMed: 9288495]

42. Agency for Toxic Substances and Disease RegistryToxicological Profile for Lead US Department of Health and Human Services; Atlanta, GA: 1999

43. Centers for Disease Control and Prevention. Blood lead levels in young children-United States and selected states, 1996-1999. MMWR Morb Mortal Wkly Rep. 2000; 49:1133-1137. [PubMed: 11190117]

44. Needleman HL, Gunnoe C, Leviton A, et al. Deficits in psychologic and classroom performance of children with elevated dentine lead levels. N Engl J Med. 1979; 300:689-695. [PubMed: 763299]

45. Bellinger DC, Stiles KM, Needleman HL. Low-level lead exposure, intelligence and academic achievement: a long-term follow-up study. Pediatrics. 1992; 90:855-861. [PubMed: 1437425]

46. Canfield RL, Henderson CR Jr, Cory-Slechta DA, et al. Intellectual impairment in children with blood lead concentrations below 10 microg per deciliter. N Engl J Med. 2003; 348:1517-1526. [PubMed: 12700371]

47. Jacobson JL, Jacobson SW. Intellectual impairment in children exposed to polychlorinated biphenyls in utero. N Engl J Med. 1996; 335:783-789. [PubMed: 8703183]

48. Grandjean P, Weihe P, White RF, et al. Cognitive deficit in 7-year old children with prenatal exposure to methylmercury. Neurotoxicol Teratol. 1997; 19:417-428. [PubMed: 9392777]

49. Whyatt RM, Rauh V, Barr DB, et al. Prenatal insecticide exposures and birth weight and length among an urban minority cohort. Environ Health Perspect. 2004; 112:1125-1132. [PubMed: 15238288] 
50. Rauh V, Garfinkel R, Perera FP, et al. Impact of prenatal chlorpyrifos exposure on neurodevelopment in the first three years of life among inner-city children. Pediatrics. 2006; 118:e1845-e1859. [PubMed: 17116700]

51. Barr HM, Streissguth AP. Identifying maternal self-reported alcohol use associated with fetal alcohol spectrum disorders. Alcohol Clin Exp Res. 2001; 25:283-287. [PubMed: 11236844]

52. Longnecker MP, Klebanoff MA, Zhou H, Brock JW. Association between maternal serum concentration of the DDT metabolite DDE and preterm and small-for-gestational-age babies at birth. Lancet. 2001; 358:110-114. [PubMed: 11463412]

53. Olsen H, Burgess D, Streissguth A. Fetal alcohol syndrome and fetal alcohol effects: a lifespan view, with implications for intervention. Zero Three/Natl Cent Clin Infant Programs. 1992; 13:2429.

54. Lumley J, Oliver SS, Chamberlain C, Oakley L. Interventions for promoting smoking cessation during pregnancy. Cochrane Database Syst Rev. 2004; 3:CD001055.

55. Stewart AM. Leukemia and other neoplasms in childhood following radiation exposure in utero-a general survey of present knowledge. Br J Radiol. 1968; 41:718-719. [PubMed: 5676067]

56. Graziano JH, van Geen A. Reducing arsenic exposure from drinking water: different settings call for different approaches. Environ Health Perspect. 2005; 113:A360-A361. [PubMed: 15929873]

57. Moorman JE, Rudd RA, Johnson CA. National surveillance for asthma-United States, 1980-2004. MMWR Surveill Summ. 2007; 56:1-54.

58. Claudio L, Tulton L, Doucette J, Landrigan PJ. Socioeconomic factors and asthma hospitalization rates in New York City. J Asthma. 1999; 36:343-350. [PubMed: 10386498]

59. Corburn J, Osleeb J, Porter M. Urban asthma and the neighborhood environment in New York City. Health Place. 2006; 12:167-179. [PubMed: 16338632]

60. Gold DR, Wright R. Population disparities in asthma. Ann Rev Public Health. 2005; 26:89-113. [PubMed: 15760282]

61. Brugge DJ, Valiarino J, Ascolillo L. Comparison of multiple environmental factors for asthmatic children in public housing. Indoor Air. 2003; 13:18-27. [PubMed: 12608922]

62. Clougherty JE, Levy JI, Kubzansky LD, et al. Synergistic effects of traffic-related air pollution and exposure to violence on urban asthma etiology. Environ Health Perspect. 2007; 115:1140-1146. [PubMed: 17687439]

63. Levy J, Brugge D, Peters JL. A community-based participatory research study of multifaceted inhome environmental interventions for pediatric asthmatics in public housing. Soc Sci Med. 2005; 63:2191-2203.

64. Peters JL, Levy JI, Rogers CA. Determinants of allergen concentrations in apartments of asthmatic children living in public housing. J Urban Health. 2007; 84:185-197. [PubMed: 17216349]

65. US Department of Health and Human Services. Healthy People 2020 http:// www.healthypeople.gov/HP2020. Accessed January 2010

66. Ogden CL, Flegal KM, Carroll MD, Johnson CL. Prevalence and trends in overweight among US children and adolescents, 1999-2000. JAMA. 2002; 288:1728-1732. [PubMed: 12365956]

67. Ogden CL, Carroll MD, Flegal KM. High body mass index for age among US children and adolescents 2003-2006. JAMA. 2008; 299:2401-2405. [PubMed: 18505949]

68. Ogden CL, Carroll MD, Curtin LR, et al. Prevalence of overweight and obesity in the United States, 1999-2004. JAMA. 2006; 295:1549-1555. [PubMed: 16595758]

69. Thorpe LE, List DG, Marx T, et al. Childhood obesity in New York City elementary school students. Am J Public Health. 2004; 94:1496-1500. [PubMed: 15333301]

70. Shaw J. Epidemiology of childhood type 2 diabetes and obesity. Pediatr Diabetes. 2007; 8(suppl 9):7-15. [PubMed: 17991128]

71. James WP. The epidemiology of obesity: the size of the problem. J Intern Med. 2008; 263:336352. [PubMed: 18312311]

72. Lee JM. Why young adults hold the key to assessing the obesity epidemic in children. Arch Pediatr Adolesc Med. 2008; 162:682-687. [PubMed: 18606940]

73. Morrison JA, Ford ES, Steinberger J. The pediatric metabolic syndrome. Minerva Med. 2008; 99:269-287. [PubMed: 18497725] 
74. Zimmet P, Alberti G, Kaufman F, et al. The metabolic syndrome in children and adolescents. Lancet. 2007; 369:2059-2061. [PubMed: 17586288]

75. Zimmet P, Alberti KG, Kaufman F, et al. The metabolic syndrome in children and adolescents-an IDF consensus report. Pediatr Diabetes. 2007; 8:299-306. [PubMed: 17850473]

76. Davison KK, Birch LL. Childhood overweight: a contextual model and recommendations for future research. Obes Rev. 2001; 2:159-171. [PubMed: 12120101]

77. Jackson RJ. The impact of the built environment on health: an emerging field. Am J Public Health. 2003; 93:1382-1384. [PubMed: 12948946]

78. Galvez MP, Frieden TR, Landrigan PJ. Obesity in the 21st century. Environ Health Perspect. 2003; 111:A684-A685. [PubMed: 14527853]

79. Giles-Corti B, Macintyre S, Clarkson JP, et al. Environmental and lifestyle factors associated with overweight and obesity in Perth, Australia. Am J Health Promot. 2003; 18:93-102. [PubMed: 13677967]

80. Winterfeld A. Nutrition rules: making healthy food choices available to school kids is a priority for many lawmakers. State Legis. 2008; 34:22-24. [PubMed: 18441618]

81. Frieden TR, Bassett MT, Thorpe LE, Farley TA. Public health in New York City, 2002-2007: confronting epidemics of the modern era. Int J Epidemiol. 2008; 37:966-977. [PubMed: 18540026]

82. Glanz K, Yaroch AL. Strategies for increasing fruit and vegetable intake in grocery stores and communities: policy, pricing, and environmental change. Prev Med. 2004; 39(suppl 2):S75-S80. [PubMed: 15313075]

83. Cervero R, Duncan M. Walking, bicycling, and urban landscapes: evidence from the San Francisco Bay Area. Am J Public Health. 2003; 93:1478-1483. [PubMed: 12948966]

84. Pucher J, Dill J, Handy S. Infrastructure, programs, and policies to increase bicycling: an international review. Prev Med. 2010; 50:S106-S125. [PubMed: 19765610]

85. Tester J, Baker R. Making the playfields even: evaluating the impact of an environmental intervention on park use and physical activity. Prev Med. 2009; 48:316-320. [PubMed: 19463491]

86. Smith KR, Brown BB, Yamada I, et al. Walkability and body mass index density, design, and new diversity measures. Am J Prev Med. 2008; 35:237-244. [PubMed: 18692736]

87. Heindel JJ. Endocrine disruptors and the obesity epidemic. Toxicol Sci. 2003; 76:247-249. [PubMed: 14677558]

88. Acerini CL, Hughes IA. Endocrine disrupting chemicals: a new and emerging public health problem? Arch Dis Child. 2006; 91:633-641. [PubMed: 16861481]

89. Calafat AM, Ye X, Wong LY, et al. Exposure of the U.S. population to bisphenol A and 4-tertiaryoctylphenol: 2003-2004. Environ Health Perspect. 2008; 116:39-44. [PubMed: 18197297]

90. Sathyanarayana S, Karr CJ, Lozano P, et al. Baby care products: possible sources of infant phthalate exposure. Pediatrics. 2008; 121:e260-e268. [PubMed: 18245401]

91. Hatch EE, Nelson JW, Qureshi MM, et al. Association of urinary phthalate metabolite concentrations with body mass index and waist circumference: a cross-sectional study of NHANES data, 1999-2002. Environ Health. 2008; 7:27. [PubMed: 18522739]

92. Trasande L, Landrigan PJ. The National Children's Study: a critical national investment. Environ Health Perspect. 2004; 112:A789-A790. [PubMed: 15471708]

93. Landrigan PJ, Trasande L, Thorpe LE, et al. The National Children's Study: a 21-year prospective study of 100,000 American children. Pediatrics. 2006; 118:2173-2186. [PubMed: 17079592]

94. Landrigan PJ, Carlson JE, Bearer CF, et al. Children's health and the environment: a new agenda for prevention research. Environ Health Perspect. 1998; 106(suppl 3):787-794. [PubMed: 9646038]

95. Food Quality Protection Act of 1996 http://www.epa.gov/opp00001/regulating/laws/fqpa/ gpogate.pdf. Accessed January 2010

96. Adler NE, Ostrove JM. Socioeconomic status and health: what we know and what we don't. Ann N Y Acad Sci. 1999; 896:3-15. [PubMed: 10681884] 

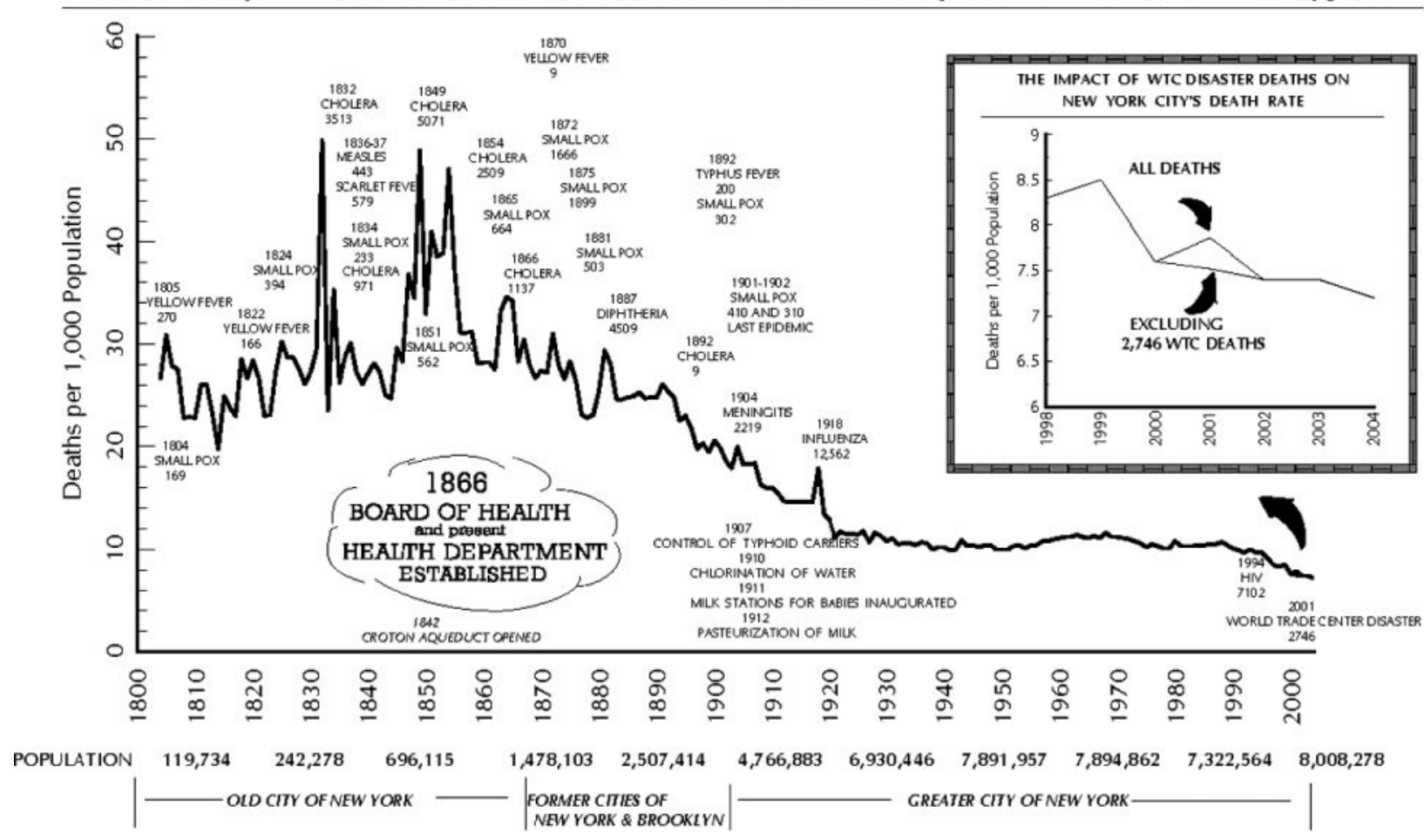

Fig 1.

Conquest of pestilence in New York City. Abbreviations: HIV, human immunodeficiency virus; WTC, World Trade Center. 


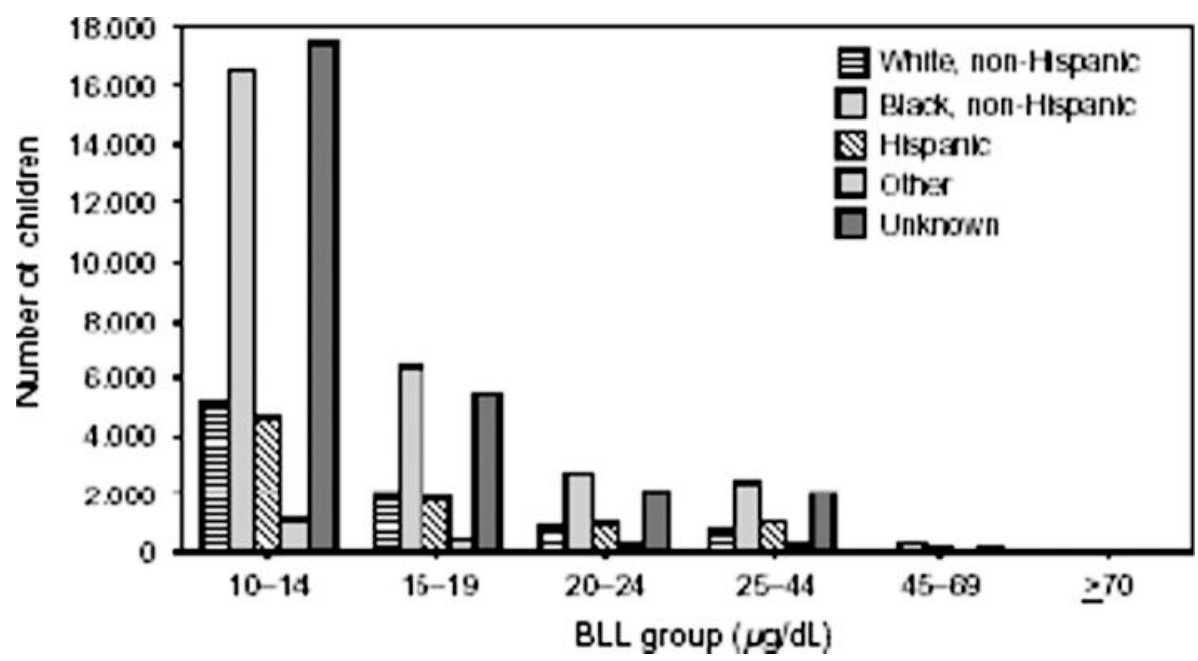

Fig 2.

Number of children with confirmed BLLs by racial or ethnic groups and program-relevant BLL groups: selected US states, 2001. Abbreviation: BLL, blood lead level. 